ISSN 0258-7122 (Print), 2408-8293 (Online)

Bangladesh J. Agril. Res. 44(4): 689-693, December 2019

Short Communication

\title{
EFFECT OF FOLIAR SPRAY OF BIOREGULATORS AND IRRIGATION ON DRY MATTER ACCUMULATION OF MUSTARD (Brassica juncea L.)
}

\begin{abstract}
A. SINGH ${ }^{1}$ AND R. S. MEENA ${ }^{2}$
Rapeseed and mustard is generally, affect by irrigation water. The rapeseedmustard is the crop that has fewer requirements of the water (Aujla et al., 2005).To alleviate the harmful effect of drought stress, bioregulators may be used to change the different metabolic and physiological activities of the plant for increasing the yield of mustard crop (Meena et al., 2013). Thiourea containing one SH group and it's is a sulphydryl compound. The SH group has been implicated in photosynthetic translocation in plants (Giaquinta, 1976). It is simply concerned in light activation of photosynthetic enzymes (Salisbury and Ross, 1986). The exogenous application of Salicylic acid (SA) has been reduced the negative effect of water stress (Khan et al., 2015) and spray of SA improve the growth of the plant (Hayat et al., 2010). Glycinebetainean important ammonium compound, it considered to be one of the most pre-dominant and effective osmoprotectants. The exogenous application of glycinebetaine improved the drought tolerance in plants (Mahmood et al., 2009; Meena et al., 2018). Hence, the study was conducted to see the effect of bioregulators on dry matter accumulation of Indian mustard under different levels of irrigation.
\end{abstract}

The experiment was conducted during the rabi (winter) seasons of 2014-15 and 2015-16 at Agricultural Research Farm, Department of Agronomy, Institute of Agricultural Sciences, Banaras Hindu University, Varanasi, India. The experimental field has clay loam soil. The soil have $\mathrm{pH} 7.58,7.60$, organic carbon $0.44 \%, 0.46 \%$, available nitrogen $217.3,224.1 \mathrm{~kg} / \mathrm{ha}$, available phosphorus $20.28,22.85 \mathrm{~kg} / \mathrm{ha}$, available potassium $219.2,226.4 \mathrm{~kg} / \mathrm{ha}$ and available sulphur $20.90,21.85 \mathrm{mg} / \mathrm{kg} / \mathrm{ha}$ during both the years, respectively. The field experiment was laid out in split plot design, where, main plot treatment: three irrigation levels (zero irrigation, one irrigation (at pre-flowering stage) and two irrigation (at pre-flowering and pod formation stage) and Sub-plots treatment: seven foliar spray of bioregulators (control, thiourea@1000ppm, thiourea@500ppm, salicylic acid @ 100ppm, salicylic acid @ 50ppm, glycinebetaine@100ppm and glycinebetaine @ 50ppm)and irrigation was applied@ $6 \mathrm{~cm}$ by V-notch method. Foliar spray was done at 50 per cent flower initiation and 50 per cent pod formation stage. Furrows were opened at a spacing of $45 \mathrm{~cm} \times 15 \mathrm{~cm}$ for the sowing of Indian mustard variety 'Ashirwad' with seed rate of $5 \mathrm{~kg} / \mathrm{ha}$. The sowing was done on $13^{\text {th }}$ November 2014 in $2014-15$ and $23^{\text {rd }}$

1\&2Department of Agronomy, Institute of Agricultural Sciences, Banaras Hindu University, Varanasi-221005 Uttar Pradesh, India. 
November 2015 in 2015-16. The N, P, K and S were applied as 100, 50,50 and $40 \mathrm{~kg} /$ haby basal application. Nitrogen and phosphorus were applied through diammonium phosphate and urea, potash and sulphur through murate of potash and elemental sulphur, respectively. The $1 / 2$ dose of $\mathrm{N}$ and full dose of $\mathrm{P}, \mathrm{K}$ and $\mathrm{S}$ were applied at sowing and $1 / 2$ dose of Ngiven at the time of first irrigation as basal dressing but full dose of NPKS was applied at the time of sowing in zero irrigation treatment. The data were analyzed as per the standard procedure for "Analysis of Variance" (ANOVA) (Gomez and Gomez, 1976).

The pooled analysis showed that the Interaction effect of levels of irrigation and foliar spray of bioregulators were observed significant on dry matter accumulation (Table 1). The result indicated that the two irrigation was produce maximum dry matter accumulation (DMA) at 80, 100 DAS (days after sowing) and at harvest with the foliar spray of thiourea@1000ppm which was statistically at par with two irrigation with foliar spray of thiourea @ 500ppm. Therefore, the application of two irrigation with foliar spray of salicylic acid @ 100 ppm gave more dry matter than two irrigation withfoliar spray of salicylic acid @ 50ppm. However, the application of two irrigation with foliar spray of glycinebetaine @ 100ppmwas recorded higher dry matter over two irrigation with foliar spray of glycinebetaine @ 50ppm. The minimum dry matter accumulation at 80,100 DAS and at harvest was recorded in zero irrigation + water spray, respectively. The maximum dry matter accumulation was recorded with the application of two irrigation (at pre flowering and pod formation stage). This might be due to the adequate soil moisture increase the availability of the nutrient in the soil for the plant to increase in growth parameters by cell elongation and cell division this ascribed due to higher activity of auxin in plant tissues and photosynthesis activity of plant so they produced more food (Mandal et al., 2006; Meenaet al., 2019). The higher value of DMA was recorded with the foliar spray of thiourea @ 1000ppm which was found statistically at par with the application of thiourea $@ 500$ ppm. This may be ascribed due to the foliar application of thiourea motivating the photosynthetic carbon fixation mechanism that enhanced the canopy of the plant (Mehta and Sumeria; 2001, Meena et al., 2020).Moreover, the favorable effect of foliar application of salicylic acid on dry matter accumulation might be due to increased photosynthetic efficiency by increased chlorophyll content, number of branches and leaf area index, which ultimately resulted in increased dry matter accumulation (Hassanein et al.,2012; Meenaet al., 2017).

The significant improvement in Dry matter accumulation of Indian mustard could be achieved by application of two irrigation + foliar spray of thiourea @1000ppm followed by two irrigation + foliar application of thiourea @ 500ppm. 


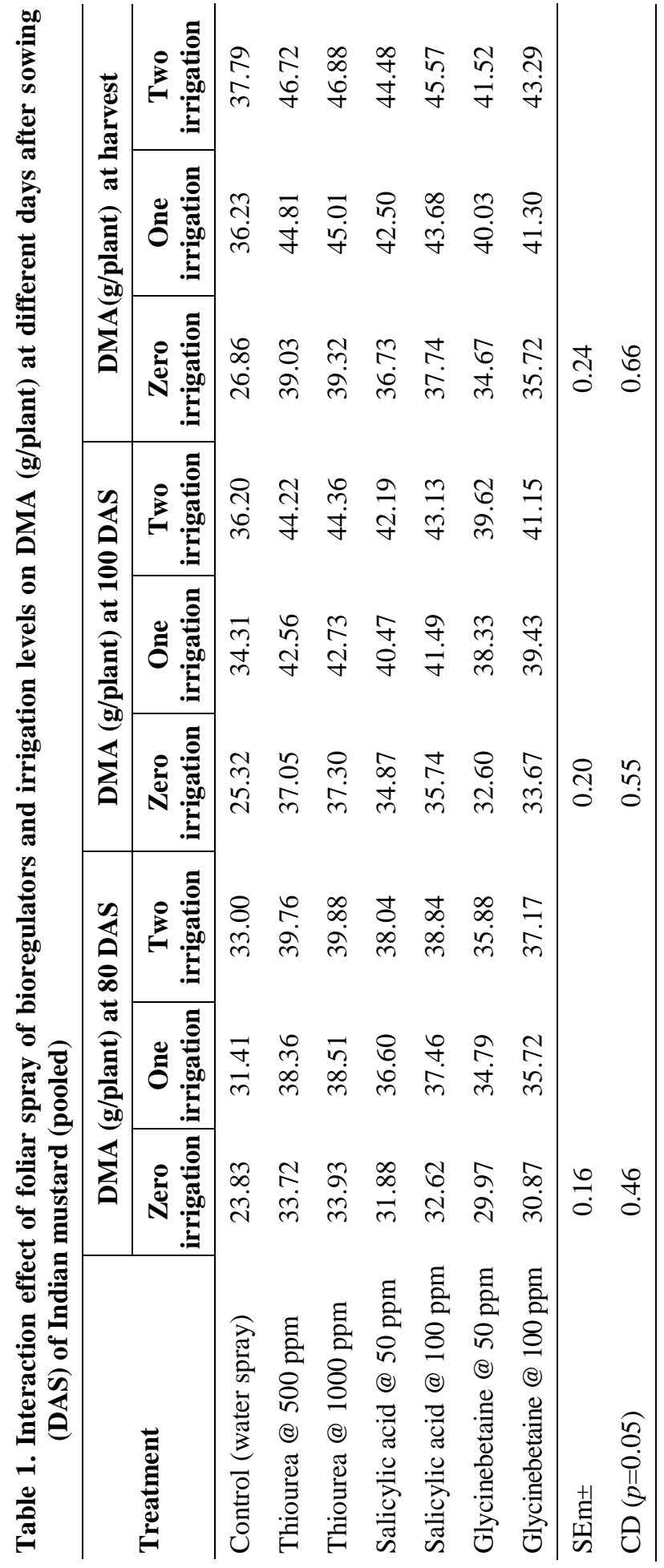




\section{References}

Aujla, M. S., H. S. Thind and G. S. Buttar. 2005. Cotton yield and water use efficiency at various levels of water and $\mathrm{N}$ through drip irrigation under two methods of planting. Agricultural Water Management.71:167-179.

Giaquinta, R. T. 1976. Evidence of phloem loading from the apoplast: Chemical modification of membrane sulphydryl group. Plant Physiology.58:872-875.

Gomez, K. A. and A. A. Gomez. 1976. Statistical Procedures for Agricultural Research, 2ndedn. John Willey and Sons Inc. New York, USA. Pp-97-101.

Hassanein, R.A., A. F. Abdelkader, H. Ali, A. A. E. Amin and E. M. Rashad. 2012. Grain primary and foliar pretreatment enhanced stress defense in wheat (Triticumaestivum var. Gimaza) plants cultivated in drought land.Australian Journal of Crop Science.6: 121-129.

Hayat, Q., S. Hayat, M. Ifran and A. Ahmad. 2010. Effect of exogenous salicylic acid under changing environment: a review. Environmental and Experimental Botany. 68: $14-25$.

Khan, M. I. R., M. Fatma, T. S. Per, N. A. Anjum and N. A. Khan. 2015. Salicylic acid on photosynthetic pigments and antioxidative enzymes of soybean plant. Frontier of Plant Science. 6:1-17.

Mahmood, T., M. Asraf and M. Shahbaz. 2009. Does exogenous application of glycine betaine as a pre-sowing seed treatment improve growth and regulate some key physiological attributes in wheat plants grown under water deficit condition. Pakistan Journal of Botany. 41(3):1291-1302.

Mandal, K. G., K. M. Hati, A. K. Misra and K. K. Bandyopadhyay. 2006. Assessment of irrigation and nutrient effects on growth, yield and water use efficiency of Indian mustard (Brassica juncea) in central India. Agricultural Water Management. 85(3):279-286.

Meena, R. K., D. D. Sharma, G. S. Chouhan, K. B. Shukla, H. K. Sumeriya and N. K. Padiwal. 2013. Growth and productivity of mustard [Brassica juncea (L.) Czern\&Coss] as influenced by irrigation levels and agrochemicals. Annals of AgriBio Research. 18(3):312-317.

Meena, R. S., S. Kumar, J. S. Bohra, R. Lal, G. S. Singh and A. Pandey. 2019. Response of alley cropping grown sesame to lime and sulphur on yield and available nutrient status in an acidic soil of Eastern India. Energy, Ecology and Environment. 4(2): $65-74$.

Meena, R. S., R. Lal and G. S. Yadav. 2020. Long-term impacts of topsoil depth and amendments on soil physical and hydrological properties of an Alfisol in Central Ohio, USA, Geoderma, Accepted.

Meena, R. S., V. Kumar, G. S. Yadav and T. Mitran. 2018. Response and interaction of Bradyrhizobiumjaponicum and Arbuscularmycorrhizal fungi in the soybean rhizosphere: A review. Plant Growth Regulation. 84:207-223. 
Meena, R. S., P. D. Meena, G. S. Yadav and S. S. Yadav. 2017. Phosphate Solubilizing Microorganisms, Principles and Application of Microphos Technology. Journal of CleanerProduction. 145: 157-158.

Mehta, Y. K. and H. K. Sumeria. 2001. Effect of plant growth regulators sulphuric acid on dry matter partitioning of pea cultivars. Haryana journal of Agronomy.17:173174.

Salisbury, F. B. and C. W. Ross. 1986. Plant Physiology. Wads Worth Publishing Company, USA, 206-207. 
